\title{
Assessment of the Environmental Impact of Noxious Emissions by Energy Enterprises into the Atmosphere of the Mining Region
}

\author{
Svetlana Grigashkina ${ }^{1,}{ }^{*}$, Maksim Grigashkin ${ }^{2}$, and Andrew Miller $^{2}$ \\ ${ }^{1}$ T.F. Gorbachev Kuzbass State Technical University, Department of Production Management \\ 650000 Kemerovo, 28 Vesennya st., Russian Federation \\ ${ }^{2}$ NUST "MISiS", Department of Energy and Energy Efficiency of the Mining Industry, 119049 \\ Moscow, 4 Leninskiy prospect, Russian Federation
}

\begin{abstract}
The article addresses the impact of harmful emissions on the environment from the activities of energy companies. The purpose of the study is to assess the environmental impact of emissions of harmful substances by energy enterprises into the atmosphere of the mining region. The analysis of the harmful impact on the environment of noxious emissions by energy enterprises into the atmosphere of the mining region is carried out. The main result of the work is the generalized SWOT-analysis of the assessment of the negative impact on the environment by noxious emissions from power plants into the atmosphere of the mining region of the Kemerovo Region; and the system of measures aimed at solving environmental problems.
\end{abstract}

\section{Introduction}

The fuel and energy complex plays an important role in the economy of the Russian Federation. As to the emission of harmful substances into the atmosphere, the fuel and energy complex takes a leading position among other industries, at the same time it has a negative impact both on the ecological and the social situation in the region creating a high social tension in the areas where energy enterprises operate. In 2016 emissions of pollutants into the air from stationary sources in 1,142 enterprises of the Kemerovo region amounted to 1,349.484 thousand tonnes, which is 5.025 thousand tons more than in 2015 from 1,115 enterprises. The air pollution load per unit area by stationary sources of the region was 14.101 tonnes / km2 [1].

The enterprises, which are part of the energy complex of the Kemerovo Region, ensure the operation of all branches of the regional economy. There are 8 thermal power plants in the region with a total installed capacity of $5041 \mathrm{MW}$ : Tom-Usinskaya GRES (state district power plants) (1272 MW); Belovskaya GRES (1200 MW); South Kuzbass GRES (554 MW);

\footnotetext{
*Corresponding author: grigashkina_si@mail.ru
} 
Kemerovskaya GRES (485 MW); Novo-Kemerovskaya TEC (combined heat and power station) (565 MW); West-Siberian TEC (600 MW); Kuznetskaya TEC (108 MW); Kemerovskaya TEC (85 MW). In parallel with the power system, there are three block stations: KMC TEC with installed electric capacity of $71 \mathrm{MW}$, Yurginskaya TEC - $91 \mathrm{MW}$, and Anzhero-Sudzhenskaya TEC - $10 \mathrm{MW}$ [2].

Electricity generation at CHPP, KES (GRES), where coal is used as fuel, is accompanied by a huge amount of air emissions. Combustion products contain gases and particulate matter, the entry of which into the air environment causes great damage to the environment. Ensuring sustainable and environmentally friendly development of the regional economy is becoming one of the priority tasks of the energy policy [3]. For this reason, the analysis of environmental activities of enterprises of the fuel and energy complex at the regional level is an urgent study.

\section{Research Methods}

The Kemerovo region operations generating and distributing electricity, gas and water are the targets of this study.

The analysis of the negative impact produced by energy enterprises on the environment by emitting noxious pollutants in the atmosphere of the mining region was carried out by an analytical method on the basis of statistical data by natural indicators (volumes of noxious emissions in the air).

A generalized assessment of the negative impact produced by energy enterprises on the environment by noxious emissions in the air of the mining region (Kemerovo Region) was performed using the SWOT analysis method

The Kemerovostat data and the official report of the Department of Natural Resources and Ecology of the Kemerovo Region were used as the source of information for the study $[1]$.

\section{Results and Discussion}

Currently, the environmental situation in the Kemerovo region is characterized by a significant impact of economic activities of manufacturing enterprises of the fuel and energy complex. The enterprises generating and distributing electricity, gas and water in the Kemerovo region are the third by the mass of pollutants emissions into the air after mineral mining enterprises and manufacturing enterprises (Figure 1) [1,4].

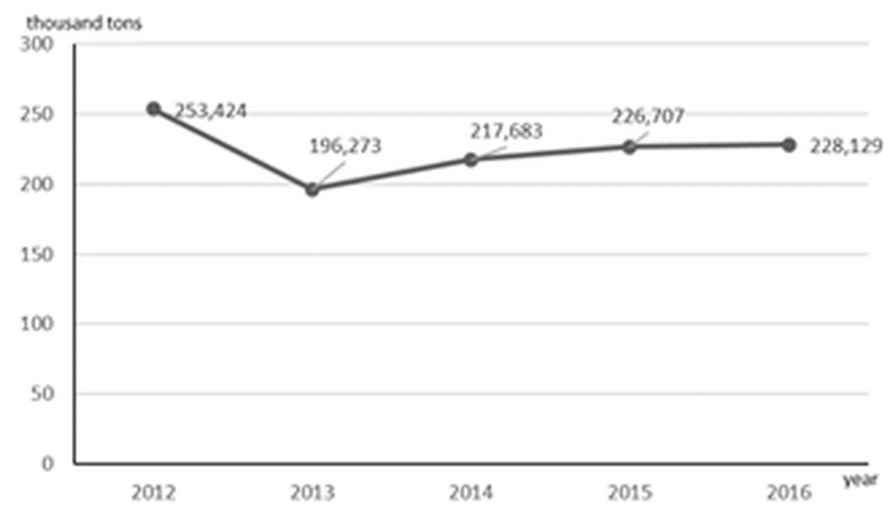

Fig. 1. Pollutants emissions in the air from stationary sources 
The trend in emissions of pollutants in the air from stationary sources by types of economic activity is shown in Table 1 [1].

Table 1. Trend in pollutants emissions from stationary sources by types of economic activity.

\begin{tabular}{|l|c|c|c|c|c|c|}
\hline \multirow{2}{*}{$\begin{array}{c}\text { Type of } \\
\text { economic } \\
\text { activity }\end{array}$} & \multicolumn{5}{|c|}{ Pollutants emitted in the air, thousand tonnes } & $\begin{array}{c}\text { Pollutant } \\
\text { emission } \\
\text { in \% }\end{array}$ \\
\cline { 2 - 7 } & $\mathbf{2 0 1 2}$ & $\mathbf{2 0 1 3}$ & $\mathbf{2 0 1 4}$ & $\mathbf{2 0 1 5}$ & $\mathbf{2 0 1 6}$ & $\mathbf{2 0 1 6}$ \\
\hline $\begin{array}{l}\text { Total for the } \\
\text { region, including }\end{array}$ & 1360.355 & 1356.297 & 1331.688 & 1344.459 & 1349.484 & 100 \\
\hline $\begin{array}{l}\text { Generation and } \\
\text { distribution of } \\
\text { electric power, } \\
\text { gas and water, of } \\
\text { which: }\end{array}$ & & 196.273 & 217.683 & 226.707 & 228.129 & 16.9 \\
\hline $\begin{array}{l}\text { generation, } \\
\text { transmission and } \\
\text { distribution of } \\
\text { electric power, } \\
\text { gas, steam and hot } \\
\text { water }\end{array}$ & 250.350 & 193.451 & 215.414 & 224.515 & 225.883 & 16.7 \\
\hline $\begin{array}{l}\text { Water collection, } \\
\text { cleaning and } \\
\text { distribution }\end{array}$ & 3.075 & 2.822 & 2.269 & 2.192 & 2.246 & 0.2 \\
\hline
\end{tabular}

The analysis of the data in Table 1 showed that the amount of emissions into the atmospheric air from the enterprises of the electric power industry in 2016 amounted to 225.883 thousand tonnes. In the territory of the Kemerovo Region there are large power plants: Belovskaya GRES, Kemerovskaya GRES, Kemerovskaya TEC, Novo-Kemerovskaya TEC, Tom-Usinsk GRES, South Kuzbass GRES, the main fuel of which is coal. During its combustion, harmful compounds are generated including nitrogen and carbon oxides, sulfur dioxide etc. [5-6]. As a result, the population of the region is exposed to negative effects of harmful substances. From 2013 to 2016, there is an increase in the amount of pollutants released into the air (Table 2) [1].

Table 2. Volumes of basic pollutants emitted by enterprises generating, transmitting and distributing electric power, gas, steam and hot water.

\begin{tabular}{|l|c|c|}
\hline Pollutant description & $\begin{array}{l}\text { Pollutants emitted in the air, } \\
\text { thousand tonnes }\end{array}$ & $\begin{array}{l}\text { Contribution in the total } \\
\text { mass of similar pollutants } \\
\text { by the region, \% }\end{array}$ \\
\hline Total, including & 225.883 & 16.7 \\
\hline Solid & 60.155 & 42.3 \\
\hline Gaseous and liquid, of which & 165.728 & 13.7 \\
\hline Sulphur dioxide & 72.831 & 58.3 \\
\hline Carbon oxide & 43.573 & 18.0 \\
\hline Nitrogen oxides & 48.323 & 64.7 \\
\hline Hydrocarbons & 0.058 & 0.0 \\
\hline Volatile organic components & 0.048 & 0.8 \\
\hline Other gaseous and liquid & 0.895 & 14.4 \\
\hline
\end{tabular}

The major pollutants typical for emissions from power plants in Kuzbass include sulfur dioxide, nitrogen and carbon oxides, ammonia, and soot. The analysis of the data in Table 2 showed that sulfur dioxides (72.83 thousand tonnes), carbon oxides (48.32 thousand tonnes), and carbon oxides (43.57 thousand tonnes) account for the greatest amount emissions in the 
pollutants structure. The major part of emissions is generated through the activities of energy companies on ensuring the operation of boiler and heating networks, supplying the population and industrial enterprises with electricity, heat and hot water [7]. In 2015, the volume of noxious emissions amounted to 224.515 thousand tonnes, in 2016, it was 225.883 thousand tonnes which is more by 1.368 thousand tonnes compared to 2015 or by $0.6 \%$ [1].

The volume of gross emissions of the main pollutants from stationary sources by types of economic activity is presented in Table 3.

Table 3. Gross emissions of major pollutants from stationary sources by types of economic activity.

\begin{tabular}{|l|l|l|l|l|l|l|}
\hline \multirow{2}{*}{$\begin{array}{l}\text { Type of economic } \\
\text { activity }\end{array}$} & \multicolumn{5}{|c|}{ Pollutants emitted in the air, thousand tonnes } & $\begin{array}{c}\text { Pollutant } \\
\text { emission } \\
\text { in \% }\end{array}$ \\
\cline { 2 - 7 } & 2012 & 2013 & 2014 & 2015 & 2016 & 2016 \\
\hline $\begin{array}{l}\text { Total for the } \\
\text { region }\end{array}$ & 154.598 & 130.816 & 138.321 & 146.136 & 142.084 & 100 \\
\hline $\begin{array}{l}\text { Generation and } \\
\text { distribution of } \\
\text { electric power, gas } \\
\text { and water, of } \\
\text { which: }\end{array}$ & 74.716 & 53.442 & 57.837 & 60.316 & 60.77 & 42.7 \\
\hline $\begin{array}{l}\text { generation, } \\
\text { transmission and } \\
\text { distribution of } \\
\text { electric power, gas, } \\
\text { steam and hot } \\
\text { water }\end{array}$ & 73.831 & 52.718 & 57.196 & 59.756 & 60.155 & 42.3 \\
\hline $\begin{array}{l}\text { Water collection, } \\
\text { cleaning and } \\
\text { distribution }\end{array}$ & 0.885 & 0.724 & 0.641 & 0.56 & 0.615 & 0.4 \\
\hline
\end{tabular}

The data presented in Table 3 show that there is a positive decreasing trend in pollutants emitted in the air from stationary sources by economic activities. However, the share of these pollutants is significant, accounting for almost half of all emissions in the Kemerovo region.

To assess the negative impact on the environment by noxious emissions in the air from energy enterprises of the mining region (Kemerovo region), the SWOT analysis method can be used (Table 4).

Table 4. The generalized SWOT analysis for assessment of the negative impact on the environment by noxious emissions in the air from energy enterprises of the mining region (Kemerovo region)

(Advantages and Disadvantages).

\begin{tabular}{|l|l|}
\hline \multicolumn{1}{|c|}{ Advantages } & \multicolumn{1}{c|}{ Disadvantages } \\
\hline $\begin{array}{l}\text { 1. The Kemerovo region fully provides itself } \\
\text { with electricity (uses its own fuel resources) }\end{array}$ & $\begin{array}{l}\text { 1. The use of coal as the main fuel without a } \\
\text { high degree purification of combustion } \\
\text { products }\end{array}$ \\
\hline $\begin{array}{l}\text { 2. Implementation of energy saving projects in } \\
\text { the territory }\end{array}$ & $\begin{array}{l}\text { 2. Violation of ecological regulations by TECs } \\
\text { and KESs (GRES) }\end{array}$ \\
\hline $\begin{array}{l}\text { 3. Major part of the region's electricity needs is } \\
\text { covered by own generation }\end{array}$ & $\begin{array}{l}\text { 3. Boilers that run on solid fuels (coal) are } \\
\text { poorly equipped or not equipped at all with } \\
\text { dust and gas cleaning equipment, or the } \\
\text { equipment is worn out and needs to be } \\
\text { replaced }\end{array}$ \\
\hline 4. Relatively cheap cost of fuel & 4. Low level of purification of energy sources \\
\hline 5. The possibility of heating and cogeneration & 5. Use of non-renewable energy resources \\
\hline
\end{tabular}


As a result of the generalized SWOT analysis of the negative impact on the environment by noxious emissions in the air from energy enterprises of the mining region (Kemerovo Region), it is possible to see more clearly the opportunities for choosing effective ways to prevent air pollution and prevent threats contributing to the development of negative events (Table 5).

Table 5. The generalized SWOT analysis for assessment of the negative impact on the environment by noxious emissions in the air from energy enterprises of the mining region (Kemerovo region)

(Opportunities and Threats).

\begin{tabular}{|l|l|}
\hline \multicolumn{1}{|c|}{ Opportunities } & \multicolumn{1}{c|}{ Threats } \\
\hline $\begin{array}{l}\text { 1. The regulatory and legal framework } \\
\text { established in the Kemerovo region regulating } \\
\text { public relations in the sphere of the } \\
\text { environment }\end{array}$ & 1. Damaged atmosphere in previous years \\
\hline $\begin{array}{l}\text { 2. Implementation of the state programs of the } \\
\text { Kemerovo Region "Ecology, Subsoil Use and } \\
\text { Rational Water Use" for 2017-2020 and } \\
\text { "Control, Protection, Reproduction, Use of } \\
\begin{array}{l}\text { Forests and Objects of the Animal World of } \\
\text { Kuzbass" for 2017-2020 }\end{array}\end{array}$ & $\begin{array}{l}\text { 2. Deterioration of technical infrastructure } \\
\text { (equipment, power lines) }\end{array}$ \\
\hline $\begin{array}{l}\text { 3. The developed regional system of } \\
\text { environmental monitoring }\end{array}$ & $\begin{array}{l}\text { 3. Negative impact of combustion products } \\
\text { (NOx, SOx, etc.) on the population (irritation } \\
\text { of upper respiratory tract, eyes, headache, } \\
\text { pathological changes) }\end{array}$ \\
\hline $\begin{array}{l}\text { 4. The created regional network of specially } \\
\text { protected areas }\end{array}$ & 4. Formation of spoil heaps \\
\hline $\begin{array}{l}\text { 5. Continuous improvement of Russian and } \\
\text { regional legislation in the area of legal support } \\
\text { for environmental protection }\end{array}$ & 5. Increasing greenhouse effect \\
\hline
\end{tabular}

The conducted assessment of the negative impact on the environment by noxious emissions in the air from energy enterprises of the mining region (Kemerovo region) has shown that the amount of noxious emissions in the air is increasing, which leads to an increase in economic damage from air pollution. On the territory of the Kemerovo region there operate 8 thermal power stations, 1207 boiler houses provide heating operating on solid fuel (coal), a significant part of them is poorly or not equipped at all with dust-gas cleaning equipment, or the equipment is worn out and needs to be replaced [1].

Combustion of solid fuel (coal) is associated with the formation of combustion products containing fly ash, sulfur dioxide (sulfurous anhydride), nitrogen oxides and other products of incomplete combustion. This leads to a negative impact on the environment, as well as on the population of the region. Ensuring energy security and improving the environmental situation in the Kemerovo region is one of the priority tasks for the near future. Particular attention should be paid to the equipment used in the boiler houses, which must meet the new requirements associated with ensuring the allowable values of air emissions of certain combustion products of solid, liquid and gaseous fuels $[5,6,8]$.

At present, the fuel and energy complex continues to produce a negative impact on the atmosphere in the mining region and this requires the introduction of new environmentally friendly technologies, including those operating on the principles of the best available technologies, and the development of effective regulators aimed at encouraging energy enterprises to environmental protection activities $[9,11]$. 


\section{Conclusions}

Thus, the conducted study of the assessment of environmental impact of noxious emissions in the air of the mining region from energy enterprises made it possible to draw the following conclusions:

- The analysis was made of noxious emissions from energy enterprises in the air of the mining region of the Kemerovo Region;

- The generalized SWOT-analysis was made for the assessment of the negative impact on the environment by noxious emissions from energy companies into the atmosphere of the mining region of the Kemerovo Region;

- The environmental problems that require immediate resolution were prioritized;

- The system of measures was proposed aimed at addressing the identified problems.

\section{References}

1. A report on the status and protection of the environment in the Kemerovo region in 2016 (AKO, Kemerovo, 2017)

2. The resolution of the Board of administration of the Kemerovo region of 31.08.2010 No. 363 "On approval of the complex regional target program" Energy saving and energy efficiency improvement of the Kemerovo region economy for 2010-2012 and for the period up to 2020" (AKO, Kemerovo, 2010)

3. A. Antoci, M. Galeotti, S. Sordi, Communications in Nonlinear Science and Numerical Simulation, 58, 262-273 (2018)

4. M. A. Uzbekov, A. K. Uzbekov, Ecological and economic aspects of conservation, 6-3, 771-774 (2012)

5. D. A. Krylov, V.E. Putintseva, Atomic Energy, 92, 529-531 (2002)

6. D. A. Krylov, Atomic Energy, 92, 523-528 (2002)

7. M. A. Gonzalez-Salazar, T. Kirsten, L. Prchlik, Renewable and Sustainable Energy Reviews, 82, 1497-1513 (2018)

8. A. Fugiel, D. Burchart-Korol, K. Czaplicka-Kolarz, A. Smoliński, Journal of Cleaner Production, 143, 159-168 (2017)

9. A. M. Abdilahi, M. W. Mustafa, International Journal of Greenhouse Gas Control Volume 63, 12-19 (2017)

10. T. I. Chamkina, Mining Information and Analytical Bulletin, 8, 268 (2008)

11. V. Zakrutkin, A. Rodina, O.S. Reshetnyak, E. Gibkov, G.YU. Sklyarenko, International Multidisciplinary Scientific Geoconference SGEM, 87, 31 (2016)

12. A.S. Marshalova, G.D. Kovaleva, G.A. Untura, Sub-Federal economic policy: problems of development and implementation in the Siberian Federal district (Nova, Moscow, 2012) 